\title{
IMPLEMENTATION OF TEACHING KEYBORDING INTO EDUCATIONAL PROGRAMS FOR PRIMARI SCHOOL OF SWITZERLAND, GERMANY AND AUSTRIA
}

\section{Iva MÁDLOVÁ}

\begin{abstract}
The article deals with the integration of teaching keyboarding into educational programs of primary schools in Switzerland, Germany and Austria. Firstly this article describes briefly the history of the typewriter development and the keyboard layout. Then it describes the way of implementation of this skill into individual education programs in above mentioned states.
\end{abstract}

Key words: keyboarding, ten-finger touch method, typing blindly.

\section{IMPLEMENTACE VÝUKY PSANÍ NA KLÁVESNICI DO VZDĚLÁVACÍCH PLÁNŮ ZÁKLADNÍCH ŠKOL ŠVÝCARSKA, NĚMECKA A RAKOUSKA}

Resumé: Článek se zabývá začleněním výuky psaní na klávesnici do vzdělávacích plánů pro základní vzdělávání ve Švýcarsku, Německu a Rakousku. Nejprve stručně popisuje historii vzniku psacího stroje a rozložení kláves na klávesnici. Poté popisuje způsob implementace této dovednosti do jednotlivých vzdělávacích plánů výše jmenovaných států.

Klíčová slova: psaní na klávesnici, desetiprstová hmatová metoda, psaní naslepo.

\section{1 Úvod}

Je tomu už více než 30 let, co společnost IBM uvedla na trh svůj první osobní počítač, který pojmenovala IBM 5150 [1]. Dnes se počet počítačů, které se ve světě používají, blíží dvěma miliardám [25]. Z těchto údajů je tedy zřejmé, že osobní počítače již pronikly do všech oblastí lidského života.

Již od svého uvedení na trh byla a je nezastupitelnou vstupní periferií počítačová klávesnice. Její ovládání je $\mathrm{v}$ současné době považováno za elementární dovednost, kterou by měl ovládat každý uživatel počítače. Vzhledem $\mathrm{k}$ tomu, že práce $\mathrm{s}$ počítačem je $\mathrm{v}$ České republice součástí obligatorní výuky již na 1. stupni základní školy, měly by základy psaní na klávesnici být zařazeny do vzdělávacích plánů v ročníku, kde tato výuka probíhá.

Hlavním problém je ovšem skutečnost, že výuka psaní na klávesnici není povinnou součástí Rámcového vzdělávacího programu pro základní vzdělávání, kterým se řídí základní školy při tvorbě svého školního vzdělávacího programu [23]. Její zařazení do učebního plánu a současně náplň vyučovacího předmětu je založeno na dobrovolnosti a motivovanosti jednotlivých škol. Učitelům psaní na klávesnici v České republice chybí legislativní ukotvení této výuky, metodické vedení a vhodné zahraniční náměty a př́klady, ze kterých by mohli čerpat.
Tato zjištění byla hlavní motivací pro obsahovou analýzu zahraničních vzdělávacích plánů států, kde mají s touto výukou bohaté zkušenosti. Hlavní výsledky provedené analýzy uvedené $\mathrm{v}$ tomto článku mohou přspět $\mathrm{k}$ rozšíření poznatků $\mathrm{v}$ oblasti výuky psaní na klávesnici a současně mohou být použity jako inspirace pro návrh implementace výuky psaní na klávesnici do Rámcového vzdělávacího programu pro základní vzdělávání v ČR.

Dř́ve než se budeme zabývat výukou psaní na klávesnici ve vybraných státech, je třeba se zaměřit na historii vzniku $\mathrm{v}$ současné době používané desetiprstové hmatové metody ovládání klávesnice, která úzce souvisí s historií vzniku a s vývojem psacích strojů.

\section{Historie psacího stroje a klávesnice}

Počátky historie psacího stroje jsou spojeny s vynálezem knihtisku. Tiskařský lis se stal inspirací pro mechanismy, které se jako první pokoušely zaznamenávat psané slovo.

Za historicky první doložený mechanismus na principu psacího stroje je považován vynález sestrojený anglickým inženýrem a technikem Henry Millem, který si jej nechal patentovat 7. ledna 1714. Bohužel se k němu do dnešní doby nedochovaly náčrty, ani samotný stroj.

V letech 1753-1760 Friedrich von Knauss sestrojil celkem šest př́strojů, které sloužily k vyřizování korespondence. $\mathrm{V}$ roce 1775 
zkonstruoval Wolfgang von Kempelen z Bratislavy psací stroj pro slepou vnučku Marie Terezie. Dopisy psané na tomto stroji jsou uloženy ve Vídeňském muzeu a v ústavu slepců v Linci. Tento psací př́stroj sestrojený primárně pro nevidomé ovšem nezůstal osamocen. Následovali ho slepecké stroje od Pingeronova, Jenkinse či Knie.

$\mathrm{Na}$ počátku 19. století se objevily snahy o sestrojení ještě dokonalejšího př́stroje, který měl urychlit zdlouhavý proces přepisování listin. Do tohoto období spadá např́klad vznik několika modelů bádenského lesníka Raise. $\mathrm{Na}$ jeho strojích se psalo akordovými úhozy, tudíž bylo možné napsat celá slova najednou. Tento př́stroj je zároveň považován za první pokus o sestrojení stenografického stroje.

Jako oficiální vynálezce psacího stroje byl na konferenci UNESCO v roce 1962 uznán Peter Mitterhofer. Ten v roce 1864 sestavil dřevěný model psacího stroje, který používal válec a př̌řad'ovač.

Na přelomu let 1865-66 sestrojil správce dánského Královského ústavu pro hluchoněmé Rasmus Malling-Hansen stroj, který nazval „skrivekuglen“, tedy psací koule. V Německu, Dánsku, Francii a Rakousku se stal prvním továrně vyráběným strojem.

Velice významným mezníkem $\mathrm{v}$ historii psacího stroje je rok 1867, ve kterém začaly pokusy vedoucí $\mathrm{k}$ sestrojení továrně vyráběného psacího stroje. Ve Spojených státech amerických (v Milwaukee) pracovali společně Carlos Glidden, Christopher Latham Sholen a Samuel W. Soule. Jejich první psací stroj dostal jméno „Typewriter“ a psal pouze velká písmena. Následoval druhý model, jenž byl vylepšen o přeřad’ovač a typové páky. Na další zlepšování již jmenovaní pánové neměli peníze. Jedním $\mathrm{z}$ těch, kteř́ se rozhodli vynálezce finančně podpořit, byl dr. Henry Roby, zpravodaj a stenograf $z$ Ohia. Tento muž se také podílel na některých vylepšeních psacího stroje, $\mathrm{k}$ nimž patří i historicky významné nově navržené uspořádání typových pák, které zamezilo jejich zasekávání. Tím vznikla univerzální klávesnice používaná dodnes ve většině zemí. Finance poskytnuté dr. Robym ovšem k tovární výrobě nestačily. Objevilo se ještě několik dalších podporovatelů, ale bohužel jejich finanční zdroje nebyly dostatečně velké, proto byla výroba těchto psacích strojů $\mathrm{v}$ roce 1873 smluvně převedena na společnost Remington. Ta, tři roky od podpisu smlouvy, zahájila tovární výrobu psacích strojů [17], [20].

$\mathrm{S}$ vývojem psacích strojů prímo souvisí i vývoj klávesnice. $V$ průběhu let měla klávesnice psacího stroje nejrůznější varianty uspořádání kláves. Tyto klávesy byly rozloženy do dvou, tří i čtyř řad. Našly se ovšem i př́stroje, které měly až deset řad. Významnou událostí, která rozhodla o rozložení kláves na klávesnici, se stal „souboj“ mezi dvěma písaři - Frankem E. McGurrinem a Louisem Taubem - dne 25. června 1888 v Cincinnati. V tomto zápolení oba muži soupeřili o to, kdo bude nejrychlejším písařem na světě. Louis Taub používal psací stroj značky Caligraph, který měl šest řad po 12 klávesách a prosazoval psaní čtyřmi prsty formou „datlování“. Naproti tomu Frank E. McGurrin psal na stroji značky Remington desetiprstovou hmatovou metodou. Tento psací stroj měl rozložení kláves QWERTY. Samotný závod obsahoval dvě části - diktát a opis neznámého textu. Každá z těchto části trvala 45 minut. Frank E. McGurrin obě dvě vyhrál a byl vyhlášen nejrychlejším písařem na světě. $\mathrm{V}$ témže roce bylo rozložení kláves QWERTY uznáno na sjezdu odborníků v Torontu [27].

Desetiprstová hmatová metoda a rozložení kláves QWERTY představuje $\mathrm{v}$ současné době mezinárodně uznávaný standard, který je uplatňován i ve výuce na školách. Nic na tom nemění skutečnost, že trh zaplavily mobilní telefony, elektronické čtečky knih apod., které lze obsluhovat prostřednictvím dotykových obrazovek. Klávesnice je stále hlavní vstupní periferií pro vkládání rozsáhlých dat do informačních systémů.

\section{Výuka psaní na klávesnici}

Má-li výuka psaní na klávesnici v České republice doznat zlepšení, je třeba se nejprve rozhlédnout po sousedních státech a poučit se $\mathrm{z}$ jejich zkušeností. $\mathrm{V}$ následující analýze vzdělávacích plánů byla pozornost zaměřena na Švýcarsko, Německo a Rakousko. Jedná se o státy, které této problematice dlouhodobě věnují značnou pozornost.

\subsection{Situace ve Švýcarské konfederaci}

Švýcarsko je tvořeno 26 kantony, které obývá necelých 8 miliónů obyvatel. Jedná se o multilingvní stát, ve kterém se oficiálně hovoří čtyřmi jazyky - německy, francouzsky, italsky a rétorománsky. Vzhledem $\mathrm{k}$ tomu, že $1 / 5$ obyvatel jsou cizinci, můžeme zde slyšet také 
srbštinu, chorvatštinu, albánštinu, portugalštinu atd. [8].

Jednotlivé švýcarské kantony mají vysokou míru suverenity. Její součástí je i oblast školství, a výuka na školách proto probíhá podle vzdělávacího plánu daného kantonu. Od záŕí 2009 je ovšem v platnosti mezikantonální dohoda HarmoS-Konkordat, jejímž ústředním posláním je sjednotit hlavní cíle vzdělávání a délku povinné školní docházky ve všech švýcarských kantonech. Tato dohoda se ovšem vztahuje pouze na kantony, které $\mathrm{k}$ této dohodě prristoupily. V tuto chvíli se jedná o 15 signatářù. Nejpozději od školního roku 2015/2016 musí tyto kantony implementovat obsah dohody do svého vzdělávání.

Povinná školní docházka je ve Švýcarsku tradičně rozdělena na primární a nižší sekundární vzdělávání (tzv. Volkschule) a trvá 9 let. $\mathrm{V}$ některých kantonech je také povinná jedno- až dvouletá docházka do mateřské školy.

Ve 21 kantonech trvá primární vzdělávání šest let a nižší sekundární vzdělávání tři roky. Zbylé kantony mají odlišnou strukturu, kdy primární vzdělávání trvá 4 , popř. 5 let a nižší sekundární vzdělávání potom 5 , popř. 4 roky.

Do povinného vzdělávání nastupují děti ve věku $5-7$ let. Na primárním stupni se učí základním dovednostem jako je čtení, psaní a počítání a navíc jsou žáci seznámeni se základy dalších předmětů. Nižší sekundární vzdělávání navazuje na předcházející stupen̆, poskytuje základní všeobecné vzdělání a prípravu na profesní život. Povinná školní docházka je zdarma pro všechny děti [21].

\subsubsection{Výuka psaní na klávesnici ve vzdělávacích plánech Švýcarska}

Vzdělávací plány jsou ve Švýcarsku zpracovány ve třech úředních jazycích. Největší počet těchto plánů, a to konkrétně 21 , jich

je dostupných $v$ němčině. Francouzskou jazykovou oblast tvoří 7 kantonů, přičemž v šesti $\mathrm{z}$ nich je francouzština používána jako hlavní úřední jazyk. Italština je hlavním úředním jazykem v kantonu Ticino a druhým úředním jazykem v kantonu Graubünden. V textu jsou ovšem použity pouze údaje $\mathrm{z}$ prvního kantonu. Informace ze vzdělávacího plánu kantonu Graubünden byly zařazeny pod německou jazykovou oblast, protože tento kanton má pouze jeden vzdělávací plán, ale ve třech jazykových verzích (kromě němčiny též $v$ italštině a rétorománštině). Analyzováno tedy bylo celkem 29 vzdělávacích plánů platných pro školní rok 2011/2012, z nichž v 26 byla výuka psaní na klávesnici obsažena.

Nejčastěji je tento předmět pojmenován př́mo „Psaní na klávesnici“ (Tastaturschreiben) a do vzdělávacích plánů je implementován bud' jako volitelný nebo povinný předmět, $v$ několika prrípadech je integrován do jiných předmětů. Což je především př́pad kantonů francouzské jazykové oblasti, které vyučují dle společného vzdělávacího plánu $\mathrm{s}$ názvem Plan d'études romand. Pro žáky nejnáročnější formu zvolil kanton Basel-Stadt (v překladu Basilej-město), kde je psaní na klávesnici realizováno prostřednictvím samostatného studia $\mathrm{v}$ pátém ročníku.

Časová dotace určená pro výuku psaní na klávesnici se pohybuje $\mathrm{v}$ rozmezí $0,5-4$ vyučovací hodiny týdně po dobu jednoho až tří let. Vybrané kantony ovšem vyučují tuto dovednost $\mathrm{v}$ průběhu celé obligatorní školní docházky. Počátek výuky této dovednosti je směřován prakticky do všech tř́́d $\mathrm{v}$ závislosti na kantonu [22], [23].

$\mathrm{V}$ následujícím přehledu jsou uvedeny vybrané výukové cíle a výstupy, kterých má být při výuce psaní na klávesnici dosaženo, případně poznámky k výukovým cílům.

\section{Kanton Appenzell Ausserrhoden}

Výstup na konci 3. třídy: Žák umí psát jednoduché texty na počítači desetiprstovou hmatovou metodou.

Výstup na konci 6. tř́ídy: Žák umí plynule psát texty desetiprstovou hmatovou metodou [10], [11].

\section{Kanton Appenzell Innerrhoden}

$\mathrm{V}$ předmětu informatika má být usilováno o rozvoj základních znalostí, dovedností a schopností v psaní na klávesnici [15].

\section{Kanton Basel-Landschaft}

Minimální standard: Žáci ovládají psaní textů desetiprstovou hmatovou metodou. Umí texty formátovat a tvořit. Dosažení tohoto cíle bude potvrzeno certifikátem [14].

\section{Kanton Glarus}

Cíl 6. tř́dy: Seznámit se s pokyny psaní na stroji podle programu Duden.

Cíl 7. třídy: Naučit se používat desetiprstovou metodu (pouze písmena a interpunkční 
znaménka); upevnit pravidla psaní na stroji podle programu Duden [16].

\section{Kanton Graubü̈nden}

Cíl: Žákyně a žáci si osvojí techniku psaní, která vyžaduje jen pohled na předlohu, nikoliv na klávesnici (psaní naslepo).

Cesta k dosažení cíle: Musí být zajištěna koncentrace na práci. Bezpečná a přesná technika úhozu pomocí rytmického psaní zvyšuje zručnost psaní. Je povinné dodržovat desetiprstovou hmatovou metodu [26].

\section{Kanton Schwyz}

Na konci 7. třídy jsou stanoveny minimální standardy pro psaní na klávesnici. V dalších ročnících se při výuce dává pozor, aby se postupně zvyšovalo tempo psaní a jistota při psaní na klávesnici [28].

\section{Kanton Solothurn}

Cíl: Efektivně využívat rozmanité funkce klávesnice.

Obsah: Desetiprstový systém [29].

\section{Kanton St. Gallen}

Dovednosti na konci 3. trrídy: Žákyně a žáci jsou schopni psát a používat vstupní zařízení.

Dovednosti na konci 6. trrídy: Žákyně a žáci jsou schopni psát plynule a srozumitelně.

Prostředek a cesta: Psaní na klávesnici.

7. - 9. tř́́da: Psaní na klávesnici. Desetiprstový systém. Ergonomie. Rytmické psaní. Psaní na klávesnici je proces, jenž musí začínat už na primárním stupni. Musí se mu věnovat pozornost při každém psaní a práci na počítači [30].

\section{Kanton Zürich}

Základní způsoby práce: Tvořit a upravovat texty a pomocí klávesnice vkládat znaky plynule a bez chyb.

Získání speciálních hardwarových nebo softwarových znalostí nebo výuka desetiprstového systému pro psaní na klávesnici jsou $\mathrm{v}$ tomto modelu jen možné kroky na cestě k cíli, a nemají být považovány za cíl samotný [3].

Kantony Genève, Berne, Fribourg, Jura, Neuchâtel, Calais, Vaud

Obsah vzdělávacího cyklu 1: Seznámení se s klávesnicí (hlavně standardními klávesami) a myší.
Očekávané výstupy: Napíše své jméno, slova, krátkou větu a umístí kurzor $\mathrm{v}$ textu pomocí myši.

Obsah vzdělávacího cyklu 2: Používání klávesnice a speciálních kláves (ctrl, delete, alt, @ ,... ). Seznámení se s psaním na klávesnici (rozložení 10 prstů, především standardní klávesy).

Očekávané výstupy: Vyhledá a používá digitální zdroje jako nástroj $\mathrm{k}$ učení. Vytvář́ dokument pomocí počítače, nahrává a samostatně ho vyhledává, kopíruje. Samostatně píše osobní text, respektuje zásady čitelnosti (rozmístění na stránce, ...) a pravopisu.

Obsah vzdělávacího cyklu 3: Procvičování ve psaní s použitím cvičebních zdrojů (píše 10 prsty, použivá standardní a speciální tlačítka/hmaty klávesnice).

Očekávané výstupy: Samostatně píše osobní text, respektuje zásady čitelnosti (rozmístění na stránce, ...) a pravopisu, (především užívá pravopisnou korekturu) [22].

\subsection{Situace ve Spolkové republice Německo}

$S$ téměř 82 milióny obyvatel patří Německo $\mathrm{k}$ největším evropským státům. Z hlediska státoprávního uspořádání je rozděleno na 16 spolkových republik, které mají vysoký stupeň autonomie. $\mathrm{Na}$ rozdíl od Švýcarska se v Německu používá pouze jeden úřední jazyk, a to němčina [7].

Vzdělávání je v Německu řízeno jednotlivými spolkovými vládami, které stanovují podmínky škol a jejich vzdělávací plány. $\mathrm{Na}$ státní úrovni jsou určovány pouze obecné rámce, jako např́íklad stejná délka povinné školní docházky, označení vzdělávacích zařízení či vzájemné uznávání získaného vzdělání [2].

Povinná školní docházka trvá ve většině spolkových zemí 9 let, v pěti spolkových zemích potom 10 let. Do školy nastupují děti zpravidla ve věku šesti let.

Primární vzdělávání zahrnuje 1. - 4. ročník, v Berlíně a Braniborsku 1. -6 . ročník. Na něho navazuje několik typů nižšího středního vzdělávání - hlavní škola, reálná škola a gymnázium. Tyto školy se mezi sebou liší $\mathrm{v}$ nárocích kladených na žáky $\mathrm{a} \mathrm{v}$ rozdílném důrazu na teorii a praxi [12].

\subsubsection{Výuka psaní na klávesnici ve vzdělávacích plánech Německa}


Analyzovány byly vzdělávací plány všech typů škol primárního i nižšího sekundárního vzdělávání jednotlivých spolkových zemí Německa. Z výsledků analýzy vyplynulo, že výuka psaní na klávesnici je obsažena ve vzdělávacích plánech čtyř spolkových zemí, a to Baden-Württemberg, Bayern, RheinlandPfalz a Saarland. Přestože se jedná pouze o čtvrtinu z celkového počtu 16 spolkových zemí, úhrnný počet obyvatel těchto zemí činí více jak 28 miliónů.

Psaní na klávesnici je ve vzdělávacích plánech integrováno do předmětů či oborů $\mathrm{s}$ různými názvy - Zpracování textu, Informačně-technické základy, Informační technologie a Němčina. Počátky výuky jsou směřovány do nejnižších ročníků nižšího sekundárního vzdělávání, a to především do 5., případně 6 . trí́dy.

Následuje přehled vybraných výukových cílů a výstupů, kterých má být při výuce psaní na klávesnici dosaženo, př́padně poznámky $\mathrm{k}$ výukovým cílům.

\section{Spolková země Baden-Württemberg}

5. - 6. tř́ída: používání počítačové klávesnice pomocí deseti prstů.

7. - 8. třída: časově efektivní používání počítačové klávesnice [4].

\section{Spolková země Bayern}

Počáteční vzdělávání (od 5. třídy)

Modul A1: Zadávání textu a editace

Žáci získají základní dovednosti v tvorbě textů a naučí se ovládat počítačovou klávesnici jako důležité vstupní zařízení. Desetiprstovou hmatovou metodu budou používat systematicky, upevní svoji dovednost a postupně budou zvyšovat vstupní rychlost.

Modul A3: Práce s textovým editorem

Žáci zvýší svoji jistotu v psaní na klávesnici hmatovou metodou a využívají možnosti formátování v systému pro zpracování texti̊. Píší plynule texty, a to pomocí vhodných metod. Uvědomují si, že úprava textu je nositelem důležitých informací a že pro tvorbu dokumentů existují pravidla a normy. Minimálně 80 úhozů na konci počátečního vzdělávání [13].

\section{Spolková země Rheinland-Pfalz}

Hlavní důraz ve výuce v 7 . a 8 . trrídě bude kladen na pečlivé ovládnutí desetiprstové hmatové metody pro racionální a zdravotně nezávadné vkládání textu na klávesnici a tvorbu textů za použití vhodného hardware a software.
Vzdělávací hodnota tohoto předmětu spočívá tedy $\mathrm{v}$ prvotním tréninku a automatizaci základních dovedností a také $\mathrm{v}$ záměrné konfrontaci s počítačem jako médiem.

Téma 1: Psaní deseti prsty

Cíl: Žákyně a žáci používají standardní klávesnici (DIN 2137) v souladu s požadavky tohoto vzdělávacího programu.

Důvod: Pouze desetiprstovou hmatovou metodou může být počítač nejlépe používán nejenom pro domácí použití, ale i ve škole a ve světě práce. Celkové téma psaní na klávesnici je třeba chápat jako univerzální princip výuky a nesmí být považován za uzavřený.

Téma 2: Použití funkčních kláves

Cíl: Žákyně a žáci budou používat funkční klávesy smysluplně a účinně.

Důvod: Smysluplné a účinné používání funkčních kláves je nezbytným doplňkem desetiprstové hmatové metody.

Téma 3: Dovednost a jistota v psaní

Cíl: Žákyně a žáci by měli při zadávání textu dosáhnout průměrnou rychlost 100 úhozů za minutu.

Důvod: Tato rychlost zápisu je považována za efektivní při použivání desetiprstové hmatové metody [18].

\section{Spolková země Saarland}

Vzdělávací cíle:

- znát a používat klávesnici pomocí desetiprstové hmatové metody;

- znát a používat alfanumerickou a numerickou klávesnici, jejíž součástí jsou pravidla psaní dle normy DIN 5008 a také funkční klávesy.

Poznámky: Při psaní deseti prsty se dbá na to, aby byl text pořizován ekonomicky, např́klad za použití klávesových zkratek a funkčních kláves. Při tom jsou žákyně a žáci upozorňováni na různé druhy chyb a jejich př́ičin. Doporučuje se provádět první hodnocení výkonu formou desetiminutového řádkového psaní. Psaní na klávesnici vyžaduje obzvlášt' na začátku velkou koncentraci, které je dosaženo pomocí klidného pracovního prostředí. Opravy př̀i sezení a držení těla a cílené protahovací cvičení pomáhají předcházet zdravotním problémům [19].

\subsection{Situace v Rakouské republice}

Rakousko je federativní republikou, jež tvoří 9 spolkových zemí s celkovým počtem obyvatel 8,2 milionů. Jediným úředním jazykem je němčina, nepatrná část obyvatel hovoří také turecky, srbsky nebo chorvatsky [6]. 
Jednotlivé spolkové země Rakouska nemají takovou míru autonomie jako výše uvedené státy a školství je řízeno centrálně prostřednictvím Spolkového ministerstva pro vyučování, umění a kulturu. Veřejné školství proto vzdělává podle jednotných plánů pro zrrizované typy škol v celé zemi.

Povinné vzdělávání začíná po dovršení šestého roku věku a trvá devět let. Primární vzdělávání (tzv. Volksschule) zahrnuje čtyři roky. Po jeho absolvování mohou žáci zvolit opět čtyřleté studium na třech typech škol: nižším stupni všeobecně vzdělávací vyšší školy, hlavní škole a nové střední škole. Poslední jmenovaný typ školy by měl do školního roku 2015/2016 nahradit hlavní školu. Poslední rok povinné školní docházky plní žáci na vyšším stupni školy nebo na jednoleté polytechnické škole [9].

\subsubsection{Výuka psaní na klávesnici ve vzdělávacích plánech Rakouska}

Následující údaje byly získány ze vzdělávacích plánů škol poskytujících v Rakousku primární a nižší sekundární vzdělávání. Z jejich analýzy je zřejmé, že výuka psaní na klávesnici je obsažena ve všech typech škol nižšího sekundárního vzdělávání a je zařazena mezi skupinu s názvem „Volitelné předměty a nezávazná cvičení".

Ve vzdělávacím plánu je tento předmět pojmenován „Psaní na stroji“ (Maschinenschreiben).

Časová dotace určená pro výuku tohoto školního předmětu je $2-8$ hodin během 4 let, a to v 5. - 8. trrídě.

U požadovaných výstupů je uvedeno následující:

Žákyně a žáci mají zvládnout psát deseti prsty naslepo (základní poloha asdf jklö) bez chyb a pečlivě bez určité rychlosti [5].

\section{Závěr}

Informace uvedené $\mathrm{v}$ článku nám dávají nahlédnout do stavu řešení problematiky výuky psaní na klávesnici na základních školách ve Švýcarsku, Německu a Rakousku. Z realizované analýzy vzdělávacích plánů uvedených zemí je zřejmé, že se této oblasti věnují detailně a mají s ní bohaté zkušenosti.

Nejrozmanitější způsoby implementace nabízejí vzdělávací plány Švýcarské konfederace, které odrážejí vysokou míru autonomie jednotlivých kantonů. V Německu je výuka psaní na klávesnici sice obsažena ve vzdělávacích plánech pouze 4 spolkových zemí, celkový počet obyvatel těchto zemí se ovšem blíží 30 miliónům. Velice kvalitně a podrobně jsou zde také zpracovány informace týkající obsahu, cílů a pokynů $\mathrm{k}$ výuce psaní na klávesnici desetiprstovou hmatovou metodou. Rakousko má v platnosti jeden centrální vzdělávací plán, v němž je řešená problematika uvedena a zařazena mezi volitelné předměty.

Jak již bylo řečeno $\mathrm{v}$ úvodu, $\mathrm{v}$ České republice není výuka psaní na klávesnici implementována do vzdělávacího plánu pro obligatorní vzdělávání. Ovládání počítačové klávesnice desetiprstovou metodou ovšem bezesporu patř́ mezi elementární dovednosti, kterými by měli disponovat již žáci základní školy. Výsledky výše uvedené analýzy lze proto využít pro diskusi nad návrhem vzdělávacího obsahu i očekávaných výstupů v souladu s Rámcovým vzdělávacím plánem pro základní vzdělávání v České republice.

Dle mého názoru se za velice zajímavé (z hlediska využití v podmínkách ČR) jeví začlenění výuky psaní na klávesnici do vzdělávacího plánu pro základní vzdělávání v německé Spolkové zemi Rheinland-Pfalz. Nejenom, že jsou $v$ něm poměrně důkladně vysvětleny důvody pro výuku této dovednosti, ale uvádí se zde i konkrétní počet úhozi̊ za minutu, který je považován za efektivní pro používání desetiprstové hmatové metody.

\section{Literatura}

[1] 1. virtuální PC muzeum (1981 - 2011): 30 let od prvního PC IBM / Lenovo. PC MUZEUM 1981-2011 [online]. 2011. [cit. 2012-10-16]. Dostupné z: http://www.pcmuzeum.cz/index. php?page $=$ data

[2] Aufbau und Struktur des Schulsystems. Deutscher Bildungsserver [online]. (C) 1996 2012. [cit. 2012-10-19]. Dostupné z: http:// www.bildungsserver.de/Aufbau-und-Strukturdes-Schulsystems-554.html

[3] BILDUNGSDIREKTION DES KANTONS ZÜRICH. Lehrplan für die Volksschule des Kantons Zürich. Zürich: Lehrmittelverlag des Kantons Zürich, 2010. ISBN 978-390-6744-735. Dostupné z: http://www.vsa.zh.ch/internet/ bildungsdirektion/vsa/de/schulbetrieb_und_unterr icht/faecher_lehrplaene_lehrmittel0.html [4] Bildungsplan 2012: Werkrealschule. MINISTERIUM FÜR KULTUR, Jugend und Sport. Landesbildungsserver Baden-Württemberg 
[online]. 2012. [cit. 2012-10-26]. Dostupné z: http://www.bildung-staerkt-

menschen.de/service/downloads/Bildungsplaene/ Werkrealschule/Bildungsplan2012_WRS_Interne t.pdf

[5] Bildungswesen in Österreich. Bundesministerium für Unterricht, Kunst und Kultur [online]. 2012. [cit. 2012-10-24]. Dostupné z: http://www.bmukk.gv.at/schulen/ bw/index.xml

[6] CIA - The World Factbook. CIA. Central Intelligence Agency [online]. 2012a. [cit. 201210-16]. Dostupné z: https://www.cia.gov/library/ publications/the-world-factbook/geos/au.html

[7] CIA - The World Factbook. CIA. Central Intelligence Agency [online]. 2012b. [cit. 201210-16]. Dostupné z: https://www.cia.gov/library/ publications/the-world-factbook/geos/gm.html

[8] CIA - The World Factbook. CIA. Central Intelligence Agency [online]. 2012c. [cit. 201210-16]. Dostupné z: https://www.cia.gov/library/ publications/the-world-factbook/geos/sz.html

[9] Das österreichische Bildungssystem. Bundesministerium für Unterricht, Kunst und Kultur [online]. 2012. [cit. 2012-10-24]. Dostupné z: http://www.bmukk.gv.at/schulen/ bw/index.xml

[10] Fächerübergreifende Unterrichtsgegenstände : Informatik. AMT FÜR VOLKSSCHULE UND SPORT [online]. 2008a. [cit. 2012-10-26]. Dostupné z: http://www.ar.ch/fileadmin/ user_upload/Departement_Bildung/Schulinforma tik/ICT-Lehrplan-MS-gruen.pdf

[11] Fächerübergreifende Unterrichtsgegenstände : Informatik. AMT FÜR VOLKSSCHULEN UND SPORT [online]. 2008b. [cit. 2012-10-26]. Dostupné z: http://www.ar.ch/fileadmin/ user_upload/Departement_Bildung/Schulinforma tik/ICT-Lehrplan-US-gelb.pdf

[12] Grundstruktur des Bildungswesens in der Bundesrepublik Deutschland. SEKRETARIAT DER STÄNDIGEN KONFERENZ DER KULTUSMINISTER DER LÄNDER IN DER BUNDESREPUBLIK DEUTSCHLAND. Ständige Konferenz der Kultusminister der Länder in der Bundesrepublik Deutschland [online]. 2012. [cit. 2012-10-19]. Dostupné z: http://www.kmk.org/fileadmin/doc/Dokumentati on/Bildungswesen_pdfs/dt-2012.pdf

[13] Informationstechnologie: Gesamtkonzept. Staatsinstitut für Schulqualität und Bildungsforschung [online]. 2008. [cit. 2012-1028]. Dostupné z: http://www.isb.bayern.de /isb/download.aspx ?DownloadFileID $=$ dc 74402c4 17006f52a2d6d1062287633

[14] Informations- und Kommunikationstechnologien (IKT). AMT FÜR VOLKSSCHULEN. Kanton Basel-Landschaft [online]. (C) 2006. [cit. 2012-08-09]. Dostupné z: http://www.lehrplan-

sek.bl.ch/kk/mensch_umwelt/ikt.html

[15] Lehrplan Volksschule. ERZIEHUNGSDEPARTEMENT. Kanton Appenzell Innerrhoden [online]. 2004. [cit. 201210-26]. Dostupné

http://www.ai.ch/dl.php/de/0drgt-

bw0d3e/Lehrplan_alle.pdf

[16] Kern- und Basisziele. DEPARTEMENT BILDUNG UND KULTUR DES KANTONS GLARUS. Kernlehrplan [online]. (C) 2002. [cit. 2012-08-09].

http://www.kernlehrplan.ch/

[17] KONŮPEK, Jaroslav a Ivana VALEŠOVÁ. Historie psacího stroje. Výzkumný ústav odborného školství: Praha, 2000.

[18] Lehrplan Wahlpflichtfach: Textverarbeitung. MINISTERIUM FÜR BILDUNG, Wissenschaft und Weiterbildung. Bildungsserver RheinlandPfalz [online]. 1999. [cit. 2012-10-28]. Dostupné $\mathrm{z}$ : http://lehrplaene.bildung-rp.de/lehrplaenenach-

faechern.html?tx_abdownloads_pi1\%5Baction\% $5 \mathrm{D}=$ getviewcatalog\&tx_abdownloads_pi $1 \% 5 \mathrm{Bca}$ tegory_uid\%5D=112\&tx_abdownloads_pi $1 \% 5 \mathrm{~B}$ cid\%5D $=5786 \& c H a s h=b 07 c 9 d 7 e 6 a 7332 a a 3 d 2 c d$ 6626f60df7f

[19] Lehrpläne der Fächer, für die keine Bildungsstandards der Kultusministerkonferenz vorliegen: Erweiterte Realschule 9. MINISTERIUM FÜR BILDUNG UND KULTUR. Bildungsserver Saarland [online]. 2001. [cit. 2012-10-28]. Dostupné z: http://www.saarland.de/dokumente/thema_bildun g/ERSLp-09.pdf

[20] NÁDBĚLA, Josef. Deseti prsty na klávesnici. Vyd. 2. Kralice na Hané: Computer Media, 2009. ISBN 978-80-7402-014-8

[21] Obligatorische Schule inkl. Kindergarten. SCHWEIZER MEDIENINSTITUT FÜR BILDUNG UND KULTUR. Educa.ch [online]. (C) 2010, 2011. [cit. 2012-08-20]. Dostupné z: http://bildungsszene.educa.ch/de/obligatorischeschule-inkl-kindergarten

[22] Plan d'études romand. Globaleducation [online]. 2008. [cit. 2012-10-24]. Dostupné z: http://www.globaleducation.ch/globallearning_fr/ resources/PER_complet.pdf 
[23] Rámcový vzdělávaci program pro základni vzdělávání. [online]. Praha: Výzkumný ústav pedagogický v Praze, 2007. [cit. 2012-08-26]. Dostupné z: http://www.vuppraha.cz/wpcontent/uploads/2009/12/RVPZV_2007-07.pdf

[24] STUNDENTAFELN DER
VOLKSSCHULE: PRIMARSTUFE UND SEKUNDARSTUFE I: STAND: SCHULJAHR 2011-2012. Schweizerischer Dokumentenserver Bildung [online]. 2011. [cit. 2012-10-24]. Dostupné http://edudoc.ch/record/100419/files/GrillesHoraires-2011.pdf

[25] Věci, které se točí kolem počítače. IHNED [online]. 2012. [cit. 2012-10-16]. ISSN 12137693. Dostupné z: http://ekonom.ihned.cz/c157858620-veci-ktere-se-toci-kolem-pocitace [26] Wahlfächer. AMT FÜR VOLKSSCHULE UND SPORT. Kanton Graubünden [online]. 1999. [cit. 2012-08-09]. Dostupné z: http://www.gr.ch/DE/institutionen/verwaltung/ek ud/avs/Volksschule/Lehrplan_OS_16_Wahlfaech er.pdf

[27] WERSHLER-HENRY, Darren S. The Iron Whim: A Fragmented History of Typewriting. Cornell ed. Ithaca: Cornell University Press, 2007. ISBN 08-014-4586-8

[28] ICT-Lehrplan. AMT FÜR VOLKSSCHULEN UND SPORT. Kanton Schwyz [online]. 2008 [cit. 2012-08-14]. Dostupné http://www.sz.ch/xml_1/internet/de/application/d 5/d2561/d23495/d23501/d26095/p26105.cfm
[29] Lehrplan Sek P für das 7. und 8. Schuljahr. DEPARTEMENT FÜR BILDUNG UND KULTUR. Kanton Solothurn [online]. 2010 [cit. 2012-08-14]. Dostupné http://www.so.ch/fileadmin/internet/dbk/evkaa/S chulentwicklung/Sekundarschulreform/Dokumen tationsordner/05_lehrplan_sek_p.pdf [30] Fachbereich Fächerübergreifendes Arbeiten. BILDUNGSDEPARTEMENT DES KANTONS ST. GALLEN. Kanton St.Gallen [online]. 2008 [cit. 2012-08-15]. Dostupné Z: http://www.schule.sg.ch/home/volksschule/rechtl iche_grundlagen/lehrplan/20081/_jcr_content/Par /downloadlist/DownloadListPar/download_3.ocF ile/5_Teilbereich_ICT_im_Unterricht.pdf

\section{Mgr. Iva Mádlová \\ Univerzita Hradec Králové, Pedagogická fakulta \\ Rokitanského 62, 50003 Hradec Králové e-mail: iva.madlova@uhk.cz}

